УДК 373.5.091.33-027.22:001.891.5:5:004

Дементісвська Ніна Петрівна

наукова співробітниця

Інститут інформаційних технологій і засобів навчання НАПНУ, м. Київ, Україна

ORCID ID 0000-0003-2985-3771

nina.dementievska@gmail.com

\title{
ПІДГОТОВКА ВЧИТЕЛІВ ДО ВИКОРИСТАННЯ ІНТЕРАКТИВНИХ КОМП'ЮТЕРНИХ МОДЕЛЕЙ ДЛЯ НАВЧАННЯ УЧНІВ ЧЕРЕЗ ДОСЛІДЖЕННЯ
}

\begin{abstract}
Анотація. Система підвищення кваліфікації вчителів закладів середньої освіти починає реформуватися. Учителі отримують свободу підвищувати свій фаховий рівень через недержавні організації, прийнятними визнаються різні форми такого навчання. Вимоги нового стандарту природничої освітньої галузі визначають уміння, пов'язані 3 дослідженнями. У статті описані основні положення навчання, яке отримало назву InquiryBased Science Education (навчання природничим наукам, що базується на дослідженнях), обгрунтовано, чому навчання 3 дослідженнями має стати важливим для освіти вчителів, які викладають предмети природничої освітньої галузі. Виклики, що постають перед учителями відповідно до основних положень НУШ та участі України в міжнародному дослідженні PISA, можуть бути реалізовані завдяки розвитку нових форм підвищення фахового рівня вчителів природничої освітньої галузі. Пропонується проведення тренінгу з формування в учнів і вчителів компетентностей, пов'язаних 3 навчанням через дослідження 3 використанням комп'ютерних моделювань. Описана, розроблена і апробована програма навчання вчителів щодо використання інтерактивних моделювань для навчання через дослідження. У статті описані деякі елементи методики проведення тренінгових занять 3 учителями, що викладають предмети природничої освітньої галузі, зокрема при проведенні фронтальних видів діяльності в класі, при виконанні учнями домашніх завдань та для супроводу практичних і лабораторних робіт. Ці види діяльності обрані 3 огляду на результати опитування вчителів щодо забезпечення засобами IКТ в класах, де вони викладають. Тренінгові вправи спираються на особливості проведення занять з учнями. Наведені онлайнові ресурси і приклади вправ, пропонованих на тренінгу вчителів фізики i біології, запропонована послідовність проведення занять з учнями. Обгрунтовані переваги використання сервісу Plickers для отримання і обробки миттєвих відповідей учнів як елементу формувального оцінювання під час проведення фронтальних форм занять 3 учнями з використанням моделей при вивченні фізики, хімії, біології.
\end{abstract}

Ключові слова: післядипломна педагогічна освіта; інтерактивні комп'ютерні моделі; навчання через дослідження; природнича освіта; тренінг.

\section{1. ВСТУП}

Навчання учнів природничим наукам у реальному світі, що швидко змінюється, має відповідати викликам, з якими учні мають бути готові впоратись у своєму житті. Традиційне навчання, в основному зосереджене на набутті учнями нових знань i виконавчих навичок за алгоритмами рішення типових задач, продовжує домінувати при викладанні природничих наук у школах. Значною мірою це відбувається завдяки тому, що на перевірку таких знань та умінь спрямовані і більшість завдань ДПА (Державної підсумкової атестації) і ЗНО (Зовнішнього незалежного оцінювання), які до цього часу відповідали вимогам чинного державного освітнього стандарту. Зараз ситуація в Україні змінюється. Прийнятий у лютому 2018 року Державний стандарт початкової освіти [1] чітко змінює пріоритети навчання природничим наукам, головною метою в якому, зокрема, передбачено: «Відкриття світу природи, набуття досвіду їі 
дослідження, пошук відповідей на запитання, спостереження за навколишнім світом, експериментування та створення навчальних моделей, вияв допитливості та отримання радості від пізнання природи». На черзі - ухвалення стандарту базової середньої освіти, який більш детально розкриє зміни, закладені реформою Нової української школи. Вимогами стандарту стають уміння виявляти і формулювати проблеми дослідження, визначати мету дослідження і висувати гіпотезу, планувати дослідження, спостерігати, експериментувати, моделювати, аналізувати та обгрунтовувати результати дослідження, формулювати висновки і здійснювати самоаналіз дослідницької діяльності. [1, с. 19].

У середній школі поки що здебільшого навчання ведеться за традиційною схемою: учитель і підручник виступають джерелами знань, а учні - приймачами. У сучасних школах до джерел знань іноді додається Інтернет, але це суттєво ситуацію не змінюе, оскільки здебільшого використовуються інформаційні і подекуди комунікаційні ресурси всесвітньої мережі, а методика навчання залишається незмінною. Щодо досліджень, то іноді вчителі вважають, що учні досліджують тоді, коли виконують за інструкціями з підручників лабораторні завдання. Однак вони, як доводять дослідження [2]-[4], навчаються працювати з приладами і обладнанням.

В Україні розгортається активна підготовка вчителів і адміністраторів освіти до впровадження педагогічних технологій у галузі природничої освіти, які дозволяти б ефективно формувати в учнів дослідницькі компетентності, уміння ідентифікувати і розв'язувати проблеми, а не тільки задачі, i діяти за чіткими інструкціями. Поки що не зазнали значних змін система навчання майбутніх освітян, післядипломна педагогічна освіта. Зміна змісту і методів навчання в державних установах - складний і тривалий процес. $\in$ надія, що до якісного покращення в підготовці і підвищенні кваліфікації вчителів мають призвести зміни в системі підвищення кваліфікації, за якими вчителі можуть отримувати знання та навички, а 3 ними й атестаційні бали не тільки в державній системі інститутів післядипломної педагогічної освіти, але й через обраних самими вчителями організації і фізичних осіб, які мають на це відповідні ліцензії (наприклад, онлайн курси на освітній платформі EdEra [5]) та навчання на закордонних курсах і семінарах/вебінарах). «Учитель, який отримав свободу навчати, має отримати й свободу навчатися. I ця свобода теж передбачена реформою. Має запрацювати принцип «гроші ходять за вчителем»: педагоги зможуть підвищувати кваліфікацію за державні кошти не лише в Інститутах післядипломної педагогічної освіти, а й в обраних самими педагогами організаціях.» [6]. Уряд затвердив відповідний Порядок [7]. Важливим, на нашу думку, може стати законодавчо встановлене урізноманітнення форм підвищення кваліфікації: інституційна (очна (денна, вечірня), заочна, дистанційна, мережева), дуальна, на робочому місці, на виробництві тощо. Основними видами підвищення кваліфікації зазначені такі, як навчання за програмою підвищення кваліфікації; стажування; участь у семінарах, практикумах, тренінгах, вебінарах, майстер-класах тощо.

Зміни в якості підвищення кваліфікації вчителів природничих дисциплін відбуваються після оприлюднення результатів міжнародного дослідження якості освіти PISA, започаткованого Організацією економічного співробітництва та розвитку (OECD), у якому Україна бере участь з 2018 року. Це дослідження оцінює види грамотності, серед яких одне 3 провідних місць займає природничо-наукова. Результати цих досліджень надають доказові дані про якість освіти і допомагають урядам у всьому світі ефективно використовувати бюджет і змінювати освітню політику там, де це найбільше потрібно. “Дослідження має на меті визначити рівень компетентностей, тобто здатність підлітків використовувати знання і вміння, отримані в школі, за можливих життєвих труднощів і викликів. У дослідженні визначаються не лише 
компетентності учнів, але й їхня навчальна мотивація, віра в себе, дотримання певних стратегій навчання." [8]. Це дослідження може стати додатковою мотивацією для українських учителів у використанні інтерактивних комп'ютерних моделей для навчання через дослідження ще й тому, що, починаючи з 2015 року, в комп'ютерному варіанті завдань для учнів з розділу Science (Природничі науки) використовуються саме такі комп'ютерні моделі, а в наступному дослідженні 2021 року Україна планує брати участь уже не в бланковій (паперовій), а в комп'ютерній версії тестування. Учителі мають підготувати своїх учнів до вирішення тестових завдань 3 інтерактивними комп'ютерними моделями.

Проте, попри вищезазначені виклики, які стоять перед українською природничою освітою, вітчизняних наукових статей та розробок щодо навчання вчителів педагогічних технологій формування компетентностей, пов'язаних з навчанням через дослідження, поки що небагато, наукових досліджень, здійснених в Україні на практичному матеріалі навчання вчителів і учнів України, не опубліковано. Оскільки практичного досвіду з впровадження навчання вчителів викладання природничих наук 3 елементами досліджень поки що у нас бракує, опубліковані дослідження і праці зосереджені здебільшого на змінах у змісті навчання і використанні нових ІКТ-засобів, а не на вдосконаленні методики проведення занять як з учителями, так і з учнями. Опубліковані праці часто носять теоретичний характер 3 поодинокими прикладами практичних завдань, які можуть бути запропоновані вчителям і учням [9], [10] -[11].

Скористаємося напрацюваннями дослідників з інших країн, де активне навчання учнів і вчителів з використанням досліджень уже активно впроваджується з 2000 років. До найбільш розроблених напрямків навчання з використанням досліджень можна зарахувати, наприклад, discovery learning (англ.- навчання через відкриття) [4], [12]. Найбільш відоме, теоретично обгрунтоване і практично досліджене навчання учнів за методологією IBSE) (Inquiry-Based Science Education) - навчання природничих наук, що базується на дослідженнях. Воно впроваджується в понад 30 країнах світу. Це освітня технологія в галузі природничих наук, яка - на відміну від традиційної моделі, коли вчитель надає факти, а учні їх вивчають - дає дітям можливість досліджувати, експериментувати, ставити запитання, шукати та обгрунтовувати відповіді на основі міркувань [13]. Цікаво зазначити, що на основі опрацювання кращих практик упровадження навчання, заснованого на дослідженнях за IBSE, у США був прийнятий Національний стандарт природничої освіти (NSES), у якому $є$ шість категорій: стандарти викладання природничих наук, стандарти професійного розвитку вчителів, стандарти оцінювання в природничій освіті, стандарти змісту природничих наук, стандарти програм природничої освіти, стандарти систем природничої освіти) [14]. Ідея навчання природничих наук через дослідження має довгу історію в науковій освіті. Існує не менш тривала історія плутанини щодо того, що означає навчання природничих наук за допомогою дослідження, і незалежно від визначення, його впровадження на уроці. Навчання на основі досліджень офіційно пропагується для вдосконалення вивчення природничих наук у багатьох країнах, а 3 моменту публікації «Навчання природничих наук зараз: оновлений звіт «Педагогіка майбутнього Європи» [15] воно проголошене як одна з головних освітніх цілей для Європи.

За підходами до навчання учнів за IBSE був запропонований і новий підхід до навчання вчителів, який отримав назву Inquiry-Based Science Teaching (англ. Викладання природничих наук на основі досліджень), за яким учителів хімії, фізики, біології навчають сучасним педагогічним технологіям, що дозволяють формувати дослідницькі компетентності учнів. Опублікована велика кількість досліджень за результатами навчання вчителів. Значний внесок у такі дослідження зробили Н. Будниц (Budnitz, N), А. А.Карін (Carin, А. А.), Дж. Е.Басс, (Bass, J. Е.), Т. Л. Контан (Contant, Т. 
L), Д. Луелін (Llewellyn, D). Аналіз підходів до навчання вчителів, які використовують у навчанні учнів дослідження, докладно описані, зокрема в [16]. У статті [17] докладно описані підходи і принципи такого навчання в порівнянні з традиційним, розглянуті переваги щодо впровадження такого підходу. Їх автори подають у вигляді таблиці (Таблиця 1).

Таблиия 1

Порівняння традиційного навчання і навчання за допомогою досліджень

\begin{tabular}{|c|c|c|}
\hline & Навчання через дослідження & Традиційне навчання \\
\hline Теорія & Конструктивізм & Біхевіоризм \\
\hline Участь учнів & Активна & Пасивна \\
\hline $\begin{array}{c}\text { Залучення учнів до } \\
\text { досягнення цілей } \\
\text { навчання }\end{array}$ & Підвищується відповідальність & Знижується відповідальність \\
\hline Роль учня & Вирішує проблеми & Слідує інструкціям/настановам \\
\hline Цілі навчання & Орієнтовані на процес & Орієнтовані на результат \\
\hline Роль учителя & Гід/фасилітатор & Викладач/передавач \\
\hline
\end{tabular}

Спираючись на аналіз наукових розробок навчання учнів 3 використанням досліджень, опублікованих дослідниками з різних країн світу, автори відзначають:

$\checkmark$ учні краще навчаються, коли вони беруть активну участь у навчанні і на практиці пробують/досліджують те, чому вони навчились;

$\checkmark$ засновані на запитаннях i розв'язанні проблем методи викладання, стимулювали захоплення учнів, їх цікавість і допитливість при вивченні природничих наук;

$\checkmark$ учні краще розуміють зміст, у них формуються вміння критично та творчо мислити та покращуються навички розв'язування проблем.

У цій роботі зібрані результати досліджень особливостей викладання, зокрема зазначено: «Для вчителів, які використовують навчання 3 елементами досліджень, змінюється їх роль 3 «викладача/передавача знань» і керівника на фасилітатора. Більшість вчителів стикаються 3 труднощами в скеровуванні та підтримці інтересів учнів, коли вони займаються дослідницькою діяльністю»[17]. Такі вміння фасилітації, як ефективна комунікація, здатність викликати i підтримувати інтерес учнів, використовувати скеровуючі директиви у коректній формі та стратегічного розподіляти повноваження зі своїми учнями, одночасно підтримуючи авторитет у класі, можуть стати викликом для українських учителів. Саме тому це потрібно передбачити і додати в програми підготовки вчителів. Такі заняття потребують ретельного планування навчання як учнів, так і вчителів.

Через необхідність додаткової підготовки до уроків, а також готовності до деякої невизначеності ходу уроку, яке зумовлене реакціями учнів, більшість учителів, як правило, вдаються до більш структурованих та організованих способів навчання [18]. Учителям простіше допомагати учням покроковою інструкцією здобувати зміст, а не дозволяти їм самостійно займатися навчально-дослідницькою діяльністю, ставити запитання і шукати відповіді. Прямий директивний підхід до навчання вважається найкращим методом викладання для засвоєння змісту та вироблення нових навичок. Однак «пряме викладання» також має свої обмеження. Існує тенденція, що таке викладання обмежує розвиток в учнів процесуальних навичок та вмінь формулювати власні судження, чого можна досягти навчанням через дослідження. [19]. Вищенаведені порівняння дають вчителям вагомі аргументи для застосування дослідницького підходу до викладання природничих наук замість «прямого 
викладання». Водночас, навички та знання вчителів також розширюються під час занять 3 удосконалення своєї здатності керувати класом. Викладачі стають мотивованими і підготовленими до поліпшення комунікативних навичок, що сприяє ефективному навчанню учнів.

Дослідники [20], [21] тісно позв'язують навчання 3 дослідженнями і через дослідження 3 використанням інтерактивних комп'ютерних моделей при вивченні природничих наук.

Мета статті. Метою статті $є$ висвітлення підходів до навчання через дослідження та опис елементів організації та проведення навчання вчителів, що викладають предмети природничої освітньої галузі, щодо формування в учнів навичок дослідження з використанням інтерактивних комп'ютерних моделей.

\section{2. РЕЗУЛЬТАТИ ДОСЛІДЖЕННЯ}

На основі опрацювання наукових досліджень та за проміжними результатами виконання науково-дослідної роботи ІІТЗН НАПН України «Система комп’ютерного моделювання пізнавальних завдань для формування компетентностей учнів 3 природничо-математичних предметів» (НДР №0118U003160), на підставі угод про співробітництво, укладених з Комунальним закладом «Центр інноваційних освітніх технологій» Фастівської міської ради Київської області, запроваджений практичноорієнтований проєкт для вчителів «Формування дослідницьких компетентностей учнів з використанням інтерактивних комп'ютерних моделей», з метою апробації результатів дослідження. У ньому беруть участь учителі фізики і біології 8 шкіл м. Фастова Київської області та їх учні. Учителі одного невеликого міста були обрані для апробації результатів дослідження тому, що за таких умов видається реальним відслідкувати зміни у викладанні і в навчанні учнів. У проєкті беруть участь учителі шкіл різного типу (школи I-II та I-III ступенів, НВК, школи з поглибленим вивченням окремих предметів, ліцей, гімназія, вечірня загальноосвітня школа), у яких навчаються учні 3 різним рівнем знань та комп'ютерних навичок, що деякою мірою відображає реальну ситуацію в більшості шкіл країни.

Інтерактивні комп'ютерні моделі обрані як засіб формування в учнів дослідницьких компетентностей, оскільки вони широко доступні, дозволяють проводити віртуальний експеримент безліч кількість разів; практично не обмежені використанням приладів і матеріалів для дослідження; безпечні у використанні (за умов забезпечення комп'ютерної і інтернет-безпеки), доступні для виконання як в умовах класу, так і для виконання домашніх завдань; викликають зацікавлення учнів з огляду на використання IКТ.

За результатами дослідження в межах теми обгрунтовано та обрано декілька якісних онлайнових ресурсів 3 інтерактивними комп'ютерними моделями [22]. Для вчителів фізики, хімії і біології пропонуються інтерактивні комп'ютерні моделі інтернет-ресурсу Phet «Інтерактивні симуляції для природничих наук і математики» (https://phet.colorado.edu/), створеного за ініціативи і підтримки лауреата Нобелівської премії з фізики, популяризатора науки Карла Вімана. Сайт 32002 року постійно оновлюється командою висококваліфікованих педагогів і розробників та підтримується міжнародною командою волонтерів-перекладачів, педагогами-практиками i науковцями всього світу. Автором статті перекладено українською мовою 123 інтерактивні комп'ютерні моделі з фізики, хімії, біології, математики, методичні рекомендації щодо використання всіх перекладених українською мовою моделей. Сайт також відтепер доступний для вчителів українською мовою, для чого в нижньому спадаючому меню Choose Language (Оберіть мову) слід обрати «українська». Також на 
цьому ресурсі вміщено понад 2063 розробок уроків та 125 статей науковців 3 різних країн світу. На сайті і в статтях інтерактивні комп’ютерні моделі названі симуляціями (simulation), що відповідає перекладу цього терміну в «Англо-українському тлумачному словнику 3 обчислюваної техніки, інтернету і програмування» ${ }^{1}$. У даній статті ці терміни використані як синоніми.

Для вчителів біології, крім цього ресурсу, пропонуються онлайнові інтерактивні моделі сайту OLABS (Індія, https:/www.olabs.edu.in/). Моделі цього ресурсу поступаються аналогічним з сайту Phet за кількістю елементів керування симуляціями, ïx діапазоном, можливістю працювати на сайті тільки за наявності інтернету (не можна завантажувати на переносні носіі), відсутністю цікавих і таких, що викликають захоплення учнів, елементів (як, наприклад, елементи гри) та пропонованих учителю методичних розробок і дослідницьких робіт. Проте сайт відповідає більшості критеріїв, розроблених у межах науково-дослідної теми.

За результатами вхідного опитування 232 учнів шкіл, які беруть участь у практично-орієнтованому проєкті, з'ясовано, що 70\% старшокласників ніколи не використовували інтерактивні комп'ютерні моделі ні з учителями, ні самостійно при виконанні домашніх завдань. Виявили бажання використовувати моделі при вивченні природничих наук 86\% старшокласників. Так, 38\% зазначили, що, на їх думку, навчатися 3 моделями набагато цікавіше, 17\% - що з комп’ютерними моделями їм буде зрозуміліше, легше опановувати навчальний матеріал. Більшість учнів відзначали, що таке навчання буде новим для них і сучасним. 58,1\% учнів 3 числа тих, хто вже знайомий з комп'ютерними моделями, відповіли, що вони самостійно знаходять в мережі інтернет і завантажують їх при підготовці домашніх завдань, а от у школі під керівництвом учителя - лише 13,5\%. Цікаво, що на запитання про переваги таких моделей у навчанні 48,6\% з числа тих, хто вже знайомий з моделями, відповіли, що вони краще можуть уявити ті процеси і явища, які вивчаються в школі.

325 опитаних учителів тільки 4 хоча б один раз використовували інтерактивні комп'ютерні моделі в навчальній діяльності. 40\% учителів 3 числа тих, хто не застосовує інтерактивні комп'ютерні моделі на своїх уроках, відзначили, що вони не роблять цього тому, що не мають достатньої інформації про використання симуляцій, та ще $20 \%$ - що не володіють методикою їх використання. У порівнянні з кількістю учнів, які самі знаходять і користуються інтерактивними комп'ютерними моделями, це свідчить, зокрема, про те, що учні вже самостійно знаходять і користуються такими моделями, а педагоги ще трохи “відстають” від них. Переважна більшість учителів (24 особи) на початку навчання вважали, що навчають учнів досліджувати при виконанні ними лабораторних робіт. Проте коли під час тренінгів були докладно розглянуті вимоги державного освітнього стандарту НУШ щодо навчання 3 дослідженнями [1], практично всі вчителі визнали, що в традиційному навчанні вони цього не робили раніше. Лише $2 \%$ учнів в опитуванні правильно розташували етапи дослідження.

Опитування вчителів не $є$ репрезентативним. Проте воно допомогло визначити деякі тенденції щодо реальної ситуації в школах 3 використання інтерактивних комп'ютерних моделей при викладанні предметів природничої освітньої галузі i спланувати тематику проведення занять з учителями на тренінгу.

На основі результатів опитування вчителів було встановлено, що 46,6\% мають доступ до інтернету в класах, де вони викладають, з виділеної лінії та Wi-Fi, 33,3\% тільки з мобільного пристрою, решта - не мають доступу до всесвітньої мережі. Якщо вчителю разом зі всіма учнями потрібно скористатися комп'ютерним класом, то лише 26,7\% відповіли, що завжди можуть про це домовитися з адміністрацією школи, а 40\%

\footnotetext{
«Англо-український тлумачний словник з обчислюваної техніки, інтернету і програмування». - Вид.2. К.:Видавничий дім «СофтПрес», 2007. Стор.468.
} 
дуже рідко або ніколи про це домовитися не можуть. Отже, вчителі практично не мають можливості разом з учнями постійно працювати на персональних комп'ютерах на своїх уроках 3 природничих предметів. Причиною такого стану $\epsilon$ те, що в комп'ютерних класах майже постійно впродовж навчального дня проводяться уроки інформатики. У школах, які беруть участь у проєкті, немає можливостей проводити заняття з природничих наук за технологією BYOD (Bring Your Own Device - принеси свій власний пристрій), коли учні працюють на власних планшетах, смартбуках, хромбуках тощо. Усі опитані вчителі мають власні смартфони та майже всі хороший інтернет вдома на персональному комп'ютері. Для вчителів, у яких доступ до інтернету під час уроків ускладнений, усі моделі і методичні рекомендації до них були запропоновані на переносних носіях. Зауважимо, що під час занять рекомендується використовувати саме такі попередньо завантажені моделі, щоб убезпечити проведення демонстрацій від непередбачуваних збоїв у мережі. Передбачаємо, що подібна ситуація з використанням ІКТ складається в більшості шкіл України.

\section{1. Навчання вчителів}

За наявних умов навчання і забезпечення шкіл засобами IКТ був розроблений i запропонований учителям тренінг 3 використання інтерактивних комп'ютерних моделей для навчання через дослідження, у якому основні методичні поради i навчальні завдання були зосереджені на використанні вчителями симуляцій у класі під час проведення лекцій та фронтального експерименту, для супроводу лабораторних $\mathrm{i}$ практичних занять та для надання учням домашніх завдань з використанням симуляцій. Слід зауважити, що більшість моделей 3 сайту Phet, як i сам сайт, можливо використовувати на мобільних смартфонах, проте в цьому тренінгу такі можливості роботи з учнями докладно не розглядалися.

У межах дослідження теми були розроблені і адаптовані до умов сучасної української школи деякі елементи методики використання інтерактивних комп'ютерних симуляцій при вивченні природничих предметів, описана методика використання моделей для фронтальних занять (як супровід лекції та фронтального експерименту), для домашнього віртуального експерименту та супроводу лабораторних та практичних занять. Ці види навчальної діяльності були обрані для розробки програми навчання вчителів тому, що при анкетуванні вчителів було з'ясовано, що в усіх школах $є$ доступ до Інтернету та можливість фронтально демонструвати моделі в класах, де навчаються учні, і більшість учнів мають вдома комп’ютери.

Програма тренінгу для вчителів з формування дослідницьких компетентностей учнів 3 використанням інтерактивних комп'ютерних моделей була розроблена 3 урахуванням таких навчальних цілей:

$\checkmark$ Формування мотивації вчителів до використання навчання через дослідження, позитивне сприйняття ідей компетентнісного навчання.

$\checkmark$ Отримання слухачами базових знань про навчання через дослідження (відмінностей навчального i наукового дослідження, етапів процесу дослідження, формулювання передбачень/гіпотез, залучення учнів до всіх етапів проведення досліджень від формулювання завдань/проблем до написання висновків).

$\checkmark$ Розуміння важливості зміни ролі вчителя як фасилітатора під час навчання 3 елементами досліджень та формування готовності до впровадження змін в організації роботи класу, навчального середовища, зокрема при викладанні нового матеріалу і проведенні фронтального демонстраційного експерименту. 
Заохочення вчителів до впровадження елементів формувального оцінювання (зокрема - відслідковування змін у навчанні учнів за допомогою ресурсу для отримання миттєвого зворотного зв'язку).

$\checkmark$ Уміння здійснювати рефлексію власного викладання і сприяння формуванню в учнів уміння виконувати рефлексію власного навчання.

$\checkmark$ Уміння формулювати навчальні цілі для учнів і для себе як очікуванні результати (досяжні, вимірювані, конкретні).

Програма навчання вчителів, яка була затверджена на засіданні Вченої ради IIT3Н НАПН України (протокол №13, від 30.10 2019p.), складається з семи півторагодинних занять, які проводяться в комп'ютерному класі, частина 3 яких проводиться 3 двотижневим інтервалом для виконання вчителями завдань разом з учнями:

1 заняття. Вступ до теми. Актуальність формування в учнів дослідницьких навичок: вимоги стандартів НУШ, Міжнародне дослідження PISA 3 використанням інтерактивних комп'ютерних моделей, IBSE (Inquiry-Based Science Education) навчання природничим наукам, засноване на дослідженнях.

2 заняття. Сайт Phet: навігація, україномовна версія, переваги i обмеження використання комп'ютерних симуляцій у навчальній діяльності. Реєстрація на сайті. 3 види симуляцій на сайті (Java, Flash, HTML5) - особливості завантаження. Обладнання i комп'ютерні програми для проведення занять 3 учнями 3 використанням інтерактивних моделей. Встановлення на комп'ютері додатку Java. Загальні поради для вчителів з використання симуляцій. Технічні проблеми і шляхи їх вирішення при роботі з симуляціями.

3 заняття. Використання інтерактивних комп'ютерних моделей на лекції, при виконанні фронтального демонстраційного експерименту. Особливості і сучасні підходи (ІЛД - інтерактивна лекція/демонстрація) до проведення фронтального демонстраційного експерименту. Формулювання навчальних цілей, парна і групова робота в класі під час фронтального експерименту. Стратегії створення запитань/завдань для проведення фронтальних видів діяльності.

4 заняття. Інструменти для отримання миттєвих відповідей учнів 3 використанням інтерактивних комп'ютерних моделей (додатки Plickers, Pollev, Kahoot!, GoogleForms тощо). Реєстрація на сервісі Plickers, створення робочого кабінету, власної бібліотеки i списку класів, відслідковування прогресу в навчанні учнів. «Клікерні» запитання i завдання: приклади. Розробка «клікерних» запитань до уроків.

5 заняття. Навчання через дослідження (3 види навчальних досліджень: кероване/структуроване, з супроводом, самостійне). Формулювання навчальних цілей щодо дослідницької діяльності учнів (досяжних, вимірюваних, конкретних). Добір і розробка пізнавальних завдань для роботи з симуляціями. Формулювання гіпотез, написання висновків за результатами досліджень. Супровід лабораторних і практичних робіт з використанням симуляцій.

6 заняття. Домашні завдання з використанням інтерактивних комп'ютерних моделей. Особливості формулювання дослідницьких домашніх завдань. Перегляд прикладів домашніх дослідницьких завдань 3 використанням інтерактивних комп'ютерних симуляцій. Розробка пізнавальних дослідницьких, кількісних і якісних задач для свого класу. Завантаження і збереження симуляцій для учнів для виконання домашніх завдань. Надсилання учнями вчителю і в групу соціальних мереж результатів виконання завдань $з$ симуляціями. Особливості оцінювання домашніх дослідницьких завдань $з$ інтерактивними комп'ютерними моделями.

7 заняття. Підведення підсумків проведених занять та роботи з учнями. Обговорення вчителями-учасниками занять власного досвіду використання інтерактивних комп'ютерних моделей на уроках і в позаурочній діяльності, рефлексія власного 
навчання. Проблеми і шляхи їх вирішення. Проведення підсумкового опитування вчителів.

На тренінгу були використанні такі види занять і педагогічні технології: мінілекції тренера з презентацією; обговорення питань і проблем у парах і малих групах; заповнення форм 3 опитуваннями; відстеження індивідуального зворотного зв' язку за допомогою онлайнових інструментів для миттєвого опитування; рольова гра (учителі в ролі учнів у фрагментах уроків, які були проведені на тренінгу); читання з позначками; виконання практичних робіт на комп'ютерах; ранжування етапів проведення навчання 3 розрізними картками; вправа «Займи позицію» (інші назви цієї інтерактивної вправи «Голосуємо ногами»/«По один бік дороги»); елементи методики «перевернутий клас» (учасники готували міні-лекції з нової теми і представляли її учасникам тренінгу) тощо. Крім того, вчителі мали в період між заняттями спробувати використовувати інтерактивні комп'ютерні моделі і деякі елементи запропонованої методики у своїх реальних класах і поділитись власним досвідом.

\section{2. Організація і проведення фронтальних робіт з учнями 3 використанням комп'ютерних моделей}

Симуляції сайту Phet розроблені так, щоб допомогти учням розвинути навички дослідження, вивчаючи причиново-наслідкові зв'язки. Учителі можуть полегшити обговорення в класі, створивши такий сценарій використання моделі, за яким вони можуть запросити учнів передбачити ефект від маніпулювання змінними. У класах, де проводиться таке навчання, учні часто ставлять ще багато глибоких запитань.

Одна 3 пропонованих моделей організації роботи 3 інтерактивними комп'ютерними моделями в класі, може бути, наприклад, такою:

1. Запропоновувати учням поміркувати над проблемою (запитанням, наприклад, на кшталт «А що буде, якщо...»), яка наближена до їх реального життя. (придумати/підібрати проблему/ список подібних проблем)

2. Запропонувати учням індивідуально записати/скласти список можливих рішень (передбачень/гіпотез)

3. Обговорити ці можливі рішення з партнером або в малій групі.

4. Сформулювати спільне рішення (зафіксувати його на папері: текстом або малюнком/графіком, або в комп'ютері, або записати на диктофон у мобільному телефоні)

5. Запропонувати дослідити питання/проблему за допомогою моделі: при фронтальній демонстрації - 3 учительського комп'ютера через проєкційне обладнання на екрані; по можливості - на персональних комп'ютерах учнів ( кожна група/пара - самостійно).

6. Після віртуального експерименту запропонувати учням зробити висновки щзодо свойх передбачень, виконавши наступні завдання і відповідаючи на запитання:

$\checkmark$ Пригадати (прочитати) свої передбачення (з п. 2 і 4 ). Чи справдилися їх передбачення/حіпотези, які вони запропонували для вирішення проблеми? Чи дізналися вони щось нове, досліджуючи проблему/запитання через симуляцію?

$\checkmark$ Записати свої нові висновки щодо проблеми/запитання. Учнямпочатківцям надати «мовленнєве кліше» для висновків на кшталт: «Я передбачав, щуо...., коли .... . При роботі з симулящією я упевнився/не підтвердив, щуо..... Завдяки симулячії, я щуе дізнався, щзо ....» тощуо)

7. Учні/представники малих груп ознайомлюють зі своїми висновками або 
надають їх учителю для перевірки/або іншим малим групам для взаємоперевірки/ або копіюють/ фотографують і виставляють у спільному документі (наприклад, використовуючи сервіси Postit, Padlet, GoogleDocs тощо)

8. Учитель разом з учнями проводить обговорення і підводить підсумки.

Під час роботи учнів учитель має звернути особливу увагу не тільки і не стільки на зміст учнівських передбачень/гіпотез, висновків, скільки на хід мислення учнів, спонукаючи їх вільно висловлювати свою думку, фантазувати/експериментувати. Значну увагу слід приділити рефлексії учнів щодо власного навчання з використанням моделей. За таких обставин учитель не оцінює, не відкидає, не засуджує хибні, на його думку, ідеї учнів, а спонукає їх самим пересвідчитись і перевірити результати своїх міркувань. Адже головною метою навчального дослідження $є$ не тільки «правильний» результат, а опанування учнями методики наукового дослідження. Перевагою інтерактивних комп'ютерних моделей перед реальним дослідженням процесів/подій у цьому випадку виступає те, що такі віртуальні експерименти можна проводити безліч разів, змінюючи параметри, які в реальному експерименті за браком в шкільних кабінетах обладнання та витратних матеріалів або 3 міркувань техніки безпеки, здійснити неможливо.

Робота в парах або малих групах дозволяє учням навчатися один від одного (елементи peer education, у вітчизняній педагогіці відоме як навчання «рівнийрівному»), сприяє залученню до навчання всіх учнів, дозволяє висловитись 3 обговорюваної проблеми кожному, обговорювати складні проблеми простою, зрозумілою учням мовою; формує навички висловлювання власної думки i формулювання суджень/умовиводів. Важливим елементом такого навчання $є$ також вимога фіксації своїх попередніх припущень не тільки в усній формі, а й за допомогою записів, що привчає учнів до формулювання як передбачень/гіпотез, так і висновків на основі цих формулювань. Фіксація власних ідей у різних формах дозволяє учням ознайомитись із способами занотовування результатів і міркувань, порівнянню їх, визначенню переваг і недоліків та обгрунтованого вибору найбільш відповідної форми запису даних експерименту.

Елемент висловлення припущень стає для учнів кроком до вміння формулювати гіпотези. За умови регулярного проведення таких вправ 3 учнями вчитель має поступово переходити від вимоги висловлення простих припущень, до правильного формулювання гіпотез. Оскільки ні в педагогічних навчальних закладах, ні в системі підвищення кваліфікації працівників освіти цьому питанню не приділялась увага, то під час проведеного тренінгу з учителями були проведені окремі вправи 3 навчання їх формулювання гіпотез і методиці організації такої діяльності з учнями в умовах великого змістовного навантаження кожного уроку 3 природничих предметів i обмеженого часу на уроці для формування таких навичок.

У стислому описі програми тренінгових занять з учителями зазначено, що на заняттях були розглянуті не тільки вправи з інтерактивними комп'ютерними моделями, a й інші ІКТ-засоби підтримки навчання через дослідження. Для ефективного проведення занять з учнями і отримання миттєвого зворотного зв'язку від учнів щодо розуміння ними основних понять під час фронтальної роботи 3 інтерактивними комп'ютерними моделями в класі (при поясненні нового матеріалу) учителям запропоноване використання так званих «клікерних» запитань. Використання таких запитань при вивченні фізики описані в [23]. «Клікерні» запитання (від англ. clickклацання (мишею). Такі запитання з використанням карток сервісу Plickers (Плікерс) пропонувались учителям на кожному занятті тренінгу. Учителям, які брали участь у навчанні, було запропоновано використовувати сервіс Plickers, зважаючи на його 
переваги у використанні в класі в порівнянні з подібними інструментами (PollEv-Poll Everywere, Kahoot!, GoogleForms тощо):

$\checkmark$ Базові послуги сервісу Plickers надаються користувачам безкоштовно, на ньому спрощена реєстрація (з використанням облікового запису Google, який вже $є$ у багатьох вчителів).

$\checkmark$ Сервіс передбачає створення онлайн декількох віртуальних класів, для яких ведеться реєстрація і опрацювання всіх відповідей учнів 3 можливістю імпорту в табличний процесор MS Excel для подальшої обробки i візуалізації результатів опитувань.

$\checkmark$ Висока швидкість опитування на уроці - для налаштування i проведення опитування потрібно лише кілька хвилин.

$\checkmark$ На підготовку і створення опитувальників учитель витрачає мало часу, їх можна швидко редагувати і замінювати для різних цільових аудиторій та в залежності від навчальних цілей, які ставить учитель перед учнями конкретного класу.

$\checkmark$ Для проведення опитування в класі вчителю потрібен тільки смартфон і набір карток для учнів. Один набір карток з QR-кодами вчитель використовує в усіх класах, де викладає.

$\checkmark$ Учитель може створювати як опитування думки учнів (без однієї правильної відповіді), так і запитання з правильними відповідями. У цьому випадку на сервісі реєструються і підраховуються правильні відповіді як кожного учасника, так і групи/класу в цілому.

$\checkmark$ На відміну від багатьох інших англомовних сервісів усі сторінки і розділи ресурсу можна якісно перекладати українською мовою за допомогою відповідно налаштованого перекладача в браузері Chrome.

Суттєвою перевагою цього сервісу 3-поміж інших подібних є також те, що вчитель може використовувати цей сервіс у класі і без наявності зв'язку з Інтернетом. Одразу при підключенні мобільного пристрою до інтернету всі данні опитувань автоматично переносяться в базу даних віртуального класу вчителя на сервісі.

На наш погляд, недоліком сервісу є те, що використовується тільки декілька типів запитань (обрання однієї правильної з-поміж інших та запитання 3 зображеннями (малюнками, фото, графіками і діаграмами). Проте слід зауважити, що для отримання миттєвих відповідей щодо розуміння теми в ході фронтальних видів робіт цього інструментарію цілком достатньо. Для більш глибокого оцінювання знань і вмінь учнів вчителям можна використовувати інші онлайнові інструменти з більшим діапазоном видів запитань (Pollev, GoogleForms, Kahoot! тощо).

Використання онлайнових сервісів 3 метою активізації всіх учнів під час фронтальних видів робіт у класі відрізняється від традиційного викладання, коли вчитель здебільшого ставить уточнюючі запитання всьому класу, щоб з'ясувати, чи і що саме зрозуміли учні під час демонстрації вчителем експериментів і дослідів. За таких умов вчитель може опитати лише декількох учнів класу. Під час же «клікерного» опитування відповіді на ці запитання дають усі учні класу, що дає змогу вчителю з певною точністю встановити, як учні зрозуміли демонстрацію чи новий матеріал уроку. Такий миттєвий зворотний зв'язок від учнів дозволяє вчителю не тільки з'ясувати розуміння учнями ключових понять теми, а й своєчасно внести необхідні корективи до власного викладення матеріалу. За допомогою такого інструментарію вчитель може спостерігати хід мислення учнів, їх міркування і ставлення до ідей і тем, що вивчаються. А такі завдання неодмінно постають перед учителем, який навчає учнів за компетентнісним підходом, який передбачає формування i оцінювання ставлень учнів. Таке 
відслідковування прогресу в навчанні учнів належить до технологій формувального оцінювання, яке передбачено запроваджувати в Новій український школі.

Так, наприклад, на тренінгу під час рольової гри, де вчителі в ролі учнів ознайомлювались із завданнями моделювання за темою «Звукові хвилі»(фізика), їм було запропоноване «клікерне» запитання з використанням сервісу Plickers (Рис.1).

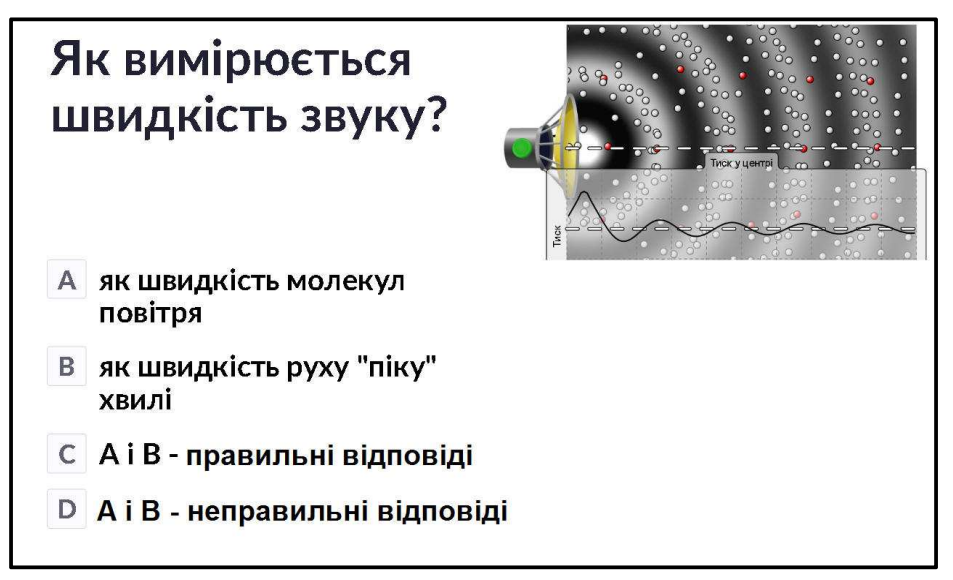

Рис. 1. Приклад використання сервісу Plickers для оцінювання сутнісних запитань теми

Учителям запропонована модель з використанням «клікерних» запитань при поясненні нового матеріалу чи фронтальному експерименті (Рис.2):

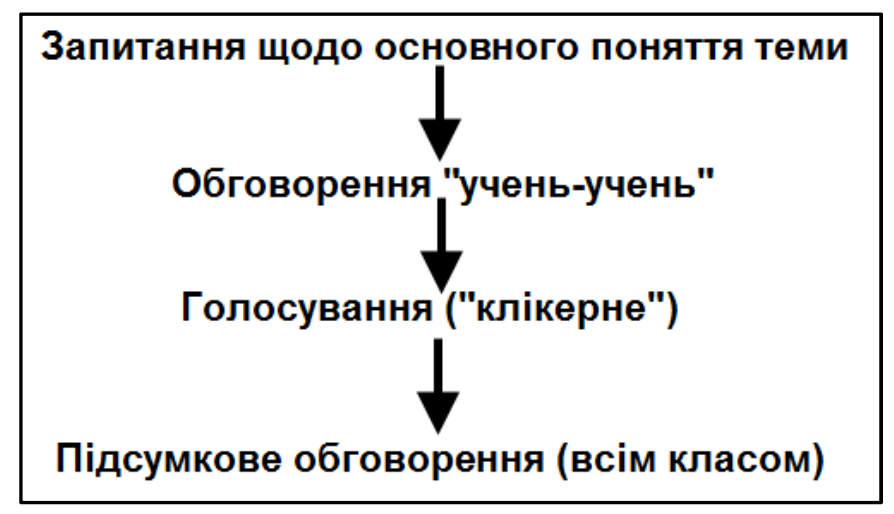

Рис.2. Схематичне зображення організації роботи в класі з клікерними запитаннями під час лекиії з використанням інтерактивних комп'ютерних моделей

За умов використання інтерактивних комп'ютерних моделей з інструментами для отримання миттєвого зворотного зв'язку під час фронтальних робіт з учнями змінюється і організація роботи класу. Зокрема на сайті Phet 3-поміж методичних рекомендацій, наданих дослідниками i запропонованих учителями-практиками «золотими зірками» (позначення розробок вчителів), відзначені саме ті, у яких пропонується така форма організації навчання, яка дозволяє формувати деякі дослідницькі навички під час фронтальної роботи в класі. Навчання має бути організовано так, щоб під час обмірковування наданого вчителем матеріалу передбачалась індивідуальна, парна і групова робота учнів.

Під час тренінгу навчання вчителів для розуміння і засвоєння ними наведеної вище педагогічної технології проведення фронтальних форм роботи з учнями та 
засвоєння наведеної послідовності дій проводилося за подібною технологією, що і пропоноване навчання учнів. Воно відбувається в 2 етапи:

1 етап. 3 учителями проводилася рольова гра, у якій вони виконували ролі учнів, а тренер виступає в ролі вчителя. Для цього можна, наприклад, використати симуляцію «Людина, що рухається», у якій «учням» пропонується досліджувати, висловлювати припущення і перевіряти їх за допомогою моделі з метою формування навичок уміння будувати і читати графіки руху тіла при прямолінійному русі. Після закінчення «уроку» учителі-учасники тренінгу за керованим тренером обговоренням з'ясовують призначення і мету кожного кроку в пропонованій технології, та які саме навички можна формувати в учнів. Водночас учителі дають відповіді на «клікерні» запитання, обговорюють свої ідеї в парах/малих групах, проводять рефлексію власного навчання. Учителям пропонується спробувати застосувати пропоновану технологію на своїх уроках для того, щоб поділитися власним досвідом на наступному занятті тренінгу.

2 етап. На наступний день тренінгу (за 2 тижні) на початку заняття кожному вчителю надається набір розрізаних карток з назвами/стислим описом кроків навчання учнів, які вони мають індивідуально розкласти за послідовністю кроків виконання такої вправи 3 учнями, потім - обговорити в парах i виробити спільне рішення i, нарешті, проголосувати за допомогою сервісу Plickers або порівняти 3 наданими тренером правильними відповідями. Після цього відбувається спільне обговорення і обмін досвідом використання подібного заняття в реальних класах з учнями. Отже, i навчання вчителів на тренінгу відбувається в порядку, визначеному на Рис.2. Такий підхід до навчання вчителів за результатами їх опитування виявився продуктивним, вони одностайно відзначили високий рівень залучення всіх учасників до обговорення проблем/задач, що вивчаються.

\section{3. Використання інтерактивних комп'ютерних моделей при виконанні учнями домашніх завдань та як супровід лабораторних $\mathbf{i}$ практичних робіт}

Дослідницьке завдання для учнів, що передбачає використання інтерактивних комп'ютерних моделей, має містити:

1. Опис проблеми/задачі. Бажано, щоб вона була з реального життя учнів цього віку, цієї місцевості і яка може бути досліджене за допомогою симуляції

2. Назву і посилання на симуляцію, яка використовується для дослідження проблеми/завдання.

3. Для учнів, які вперше працюють 3 подібними завданнями або учнів 3 особливими освітніми проблемами і мають утруднення у навчанні, слід надати покрокові інструкції для вирішення комплексного завдання i «мовленнєві кліше» для формулювання передбачень/гіпотез та написання висновків. Для таких учнів бажано надати приклад виконаного завдання 3 передбаченням, фіксацією даних і висновком

4. Перелік способів фіксації даних (текст, таблиця, схематичний малюнок, фото, відео, аудіозапис тощо).

Учителям, які вперше використовують навчання 3 дослідженнями 3 інтерактивними комп'ютерними моделями, можна запропонувати скористатися прикладами таких завдань/проблем, що вміщені на сайті Phet для кожної моделі в розділі «Для вчителів», який розташований під кожною обраною моделлю в файлі, 3 підзаголовком «Огляд симуляцій, елементів керування, спрощення в моделях та поради для розвитку мислення учнів» (у документі PDF-формату). На тренінгу вчителям був 
запропонований також додатковий перелік «Стратегії створення дослідницьких завдань/запитань» (адаптовано та доповнено з [24]):

1.Заздалегідь передбачити результат «експерименту» 3 моделлю (наприклад, «Що буде, якщо...?», «Яка зміна в налаштуванні симулящії призведе до бажаної поведінки?», «Скільки зайців залишиться через 2 роки, якщо у них будуть довгі хвости?»)

2. Ранжування (наприклад, «Яка лампочка має бути найяскравішою?», «Який рачіон для хлопчика 14p. буде оптимальним?»).

3. Порівняти контрастні випадки (наприклад, дві різні хвилі, хвилі у різних середовищах)

4. Пояснити різні зображення (наприклад, графіки, зображення, вектори).

5. Пов'язати завдання з реальним життям учнів (наприклад, «Дмитро, який стояв біля свого дому, розмовляв зі мною по своєму мобільному телефону. Сигнал телефону був поганий, тому він пройшов до дерева 5 м, намагаючись отримати кращий сигнал, $а$ потім 5 с стояв нерухомо, щуоб ми могли поговорити. Потім він пришвидшено побіг назад додому. Спрогнозуйте, як будуть виглядати графіки його перемімення $i$ швидкості. Перевірте за допомогою симуляиії «Людина, щчо рухається»)

6. Створення учнями розробки експерименту (запропонувати придумати декілька способів)

7. Визначення взаємозалежностей (що на що впливає, яка це залежність: пряма чи обернена)

8. Зробити розрахунки за законами/формулами (наприклад, «3a моделлю «Лабораторія маятників» обчислити прискорення вільного падіння на Планеті X», «Визначити матеріал, з якого зроблений невідомий об' єкт, використовуючи симуляцію «Гстина»)

Учителі-учасники тренінгу, користуючись цим переліком, визначали, які типи запитань/завдань краще підходять для фронтальних форм роботи в класі, а які - для виконання домашніх завдань. За допомогою наведених типів запитань і прикладів вони самі створювали подібні пізнавальні запитання/завдання для домашніх завдань 3 тем уроків, які вони вивчають у класах, де викладають.

Для ознайомлення учнів 3 роботою інтерактивних комп'ютерних моделей, зокрема для виконання домашніх завдань з симуляціями, рекомендовано:

$\checkmark$ Надати учням симуляцію (з інтернету - посилання на конкретну модель (для виконання домашніх завдань) або попередньо завантажене на комп'ютери і скопійоване на учнівські переносні носіі)

$\checkmark$ Продемонструвати 3 великого екрану загальний вигляд моделі i, за потреби, вкладки, з якими мають працювати учні. Учитель може при завантаженні моделі з сайту за наявності в ньому декількох вкладок, які не передбачаються для використовування учнями конкретного класу, завантажити і запропонувати учням тільки одну (декілька) потрібних вкладок, додавши до посилання на симуляцію в адресному рядку браузера символи ?screens=1, якщо, наприклад, учитель хоче завантажити/запропонувати учням тільки першу вкладку, i ?screens=1,3 - якщо тільки 1 i 3.

$\checkmark$ Бажано при першому ознайомленні 3 інтерактивними комп'ютерними моделями запропонувати учням за 3-5 хвилин самим дослідити, як взагалі працює симуляція, надавши мінімальні інструкції щодо іiі використання. Запропонувати поекспериментувати зі змінюваними параметрами, чим саме і як можна керувати, якими приладами/інструментами/засобами користуватися.

$\checkmark$ Нагадати учням завдання/проблему/запитання, які вони мають дослідити (якщо завдання комплексне і /або учні вперше працюють 3 симуляціями i/aбо для учнів 3 особливими навчальними потребами - розбити його на прості складові і надати покрокові інструкції так, щоб усі кроки були доступні таким учням і вони мали змогу 
виконувати завдання кроків у власному темпі.

$\checkmark$ Запропонувати учням фіксувати (записувати, заповнювати таблицю, фотографувати, записувати на диктофон) результати виконаних кроків. Показати учням, як можна робити екранну копію (скріншот) на комп'ютері і зберігати іiі. (Екранна копія автоматично зберігається в буфері пам'яті комп'ютера при натисканні клавіші PrintScreen на клавіатурі. Після чого її можна вставити в будь-який графічний редактор, наприклад, Paint, і зберегти файл у папці.)

На початкових етапах роботи учнів з інтерактивними комп'ютерними моделями в якості домашніх завдань рекомендуємо спочатку надавати їх тільки бажаючим учням, які згодом стануть у класі «провідниками змін». Такі учні зазвичай охоче розповідають про свій досвід одноліткам і заохочують їх навчатися з комп'ютерними симуляціями.

Важливим $є$ те, що і при першому ознайомленні з моделями, і згодом, при повторному їх використанні учнями, учителі мають пояснювати і періодично нагадувати учням, що всі моделі не відображають точно реальних процесів у природі, а тільки їх сутнісні закономірності. До майже кожної моделі з фізики, хімії, біології $з$ сайту Phet у додатковому документі 3 методичними рекомендаціями в розділі «Спрощення в моделі» наведені дані щодо того, що саме і як показане/спрощене в моделі порівняно з реальними об' єктами.

Враховуючи те, що для вивчення біології на сайті Phet значно менше інтерактивних комп'ютерних моделей, ніж для фізики і хімії, і те, що інші якісні ресурси не є україномовними, досить дорого коштують або взагалі непридатні для навчання через дослідження, учителям біології були запропоновані для використання не тільки моделі сайту «Інтерактивні симуляції для природничих наук і математики», а й моделі сайту OLABS. Моделі цього сайту, на наш погляд, можна успішно використовувати для виконання домашніх завдань та підготовки учнів до лабораторних i практичних робіт 3 біології. Перевагою цього безкоштовного англомовного онлайнового ресурсу для українських учителів біології і учнів $\epsilon$ те, що на сайті досить великий вибір моделей для біології, а також те, що всі сторінки сайту, навігаційні інструменти, написи на малюнках, етикетках, приладах і обладнанні, навіть спливаючі підказки, досить якісно автоматично перекладаються українською мовою за допомогою відповідних налаштувань у браузері Chrome (Рис. 3).

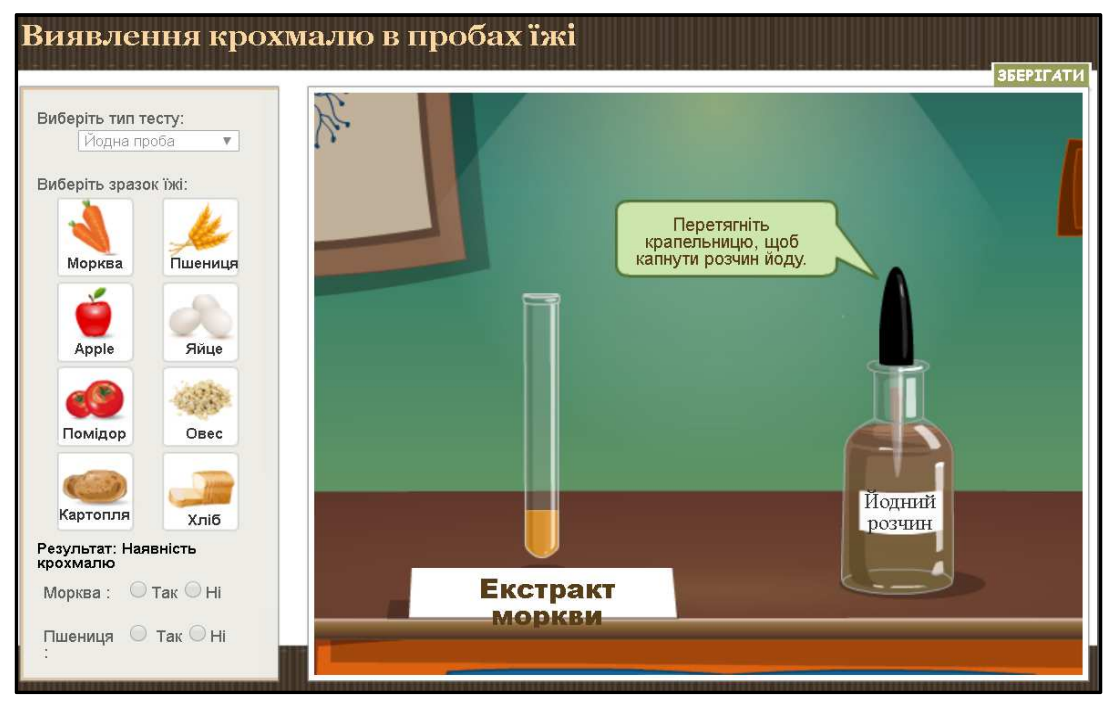

Рис. 3. Приклад інтерактивної комп'ютерної моделі з сайту OLABS, перекладеного українською мовою в браузері Chrome 
Учителі біології, які беруть участь в проєкті, схвально оцінили цей ресурс і почали його використовувати у своїх класах. Щодо використання інтерактивних комп'ютерних моделей у якості супроводу лабораторних робіт учителям запропоновано перед практичною чи лабораторною роботою, яка буде виконуватися в класі 3 реальним обладнанням, надати учням домашнє завдання - провести вдома подібний експеримент з симуляцією, запропонувати їм створити інструкцію для такого експерименту, поставити додаткові цікаві запитання щодо теми експериментальної роботи.

\section{3. ВИСНОВКИ ТА ПЕРСПЕКТИВИ ПОДАЛЬШИХ ДОСЛІДЖЕНЬ}

На основі результатів дослідження була розроблена програма навчання вчителів, що викладають предмети природничої освітньої галузі, і пройшов апробацію тренінг за цією програмою. Запропоновані елементи методики навчання через дослідження 3 використанням інтерактивних комп'ютерних моделей були використані вчителями в навчальному процесі на уроках фізики і біології. Відповідно до аналізу результатів апробації навчання вчителів внесені корективи в сценарій навчання вчителів. Після проведення тренінгу з учителями біології і фізики 8 шкіл м. Фастова Київської області вчителі хімії цих шкіл теж виявили бажання бути учасниками такого навчання. Матеріали тренінгу були адаптовані до потреб цих учителів, і з ними були проведені такі заняття.

На основі аналізу результатів індивідуальних інтерв'ю, спостережень і проведених занять 3 учителями фізики і біології внесені корективи в сценарій проведення тренінгу, а саме:

$\checkmark$ додані вправи з оцінювання і формування внутрішньої мотивації вчителів до використання запропонованих педагогічних технологій, які мають проводитися впродовж всього тренінгу;

$\checkmark$ до вхідного анкетування вчителів внесені запитання з самодіагностики рівня володіння комп'ютерними технологіями, що застосовуються в тренінгу, i проведене додаткове заняття з учителями, у яких не достатній рівень володіння комп'ютером і Інтернетом;

$\checkmark$ розроблені додаткові вправи і завдання для самостійної роботи вчителів у реальних класах щодо впровадження інтерактивних комп'ютерних моделей.

Презентації до тренінгу та додаткові матеріали і посилання на ресурси вміщені на сторінках блогу «Шкільний навчальний експеримент 3 сайтом симуляцій Phet»(https://ukrainepthet.blogspot.com/ ).

Подальших досліджень потребує вивчення результативності тренінгової методики щодо формування в учителів готовності використовувати інтерактивні комп'ютерні моделі в навчальній діяльності і вмінь упроваджувати елементи методики навчання через дослідження. Корисним може виявитися виявлення складнощів при впровадженні такого навчання і розробка шляхів їх подолання.

Цікавим i перспективним може бути розробка методичних рекомендацій i тренінгових занять щодо використання мобільних пристроїв учнів для роботи 3 симуляціями та організація проєктного навчання з використанням досліджень, а також використання їх для дистанційної та змішаної форм навчання.

3 урахуванням результатів дослідження [25], яке свідчить про те, що перед реальним досвідом викладання майбутні вчителі мають навчатися методикам, що базуються на дослідженнях, ще на рівні отримання педагогічної освіти, планується розробити подібний тренінг для студентів педагогічних університетів. Наведене дослідження доводить, що вчителі, які ознайомлюються з особливостями навчання 
через дослідження до початку викладання і яких навчали використовувати педагогічні технології, засновані на дослідженнях, швидше розробляють практичну діяльність для своїх класів; вони також мають більше шансів пов'язати наукові експерименти 3 повсякденним життям.

\section{СПИСОК ВИКОРИСТАНИХ ДЖЕРЕЛ}

[1] Кабінет Міністрів. (2018, Лют.21). Постанова №87 Державний стандарт початкової освіти. [Електронний pecypc]. Доступно: https://www.kmu.gov.ua/npas/pro-zatverdzhennya-derzhavnogostandartu-pochatkovoyi-osviti

[2] D. Kuhn, What is Scientific Thinking and How Does it Develop? In U. Goswami (Ed.), Handbook of Childhood Cognitive Development (Blackwell), 2nd ed. 2010. [Електронний ресурс]. Доступно: https://www.tc.columbia.edu/faculty/dk100/facultyprofile/files/10_whatisscientificthinkingandhowdoesitdevelop.pdf

[3] M. Bullock, B. Sodian, S. Koerber, Doing experiments and understanding science: Development of scientific reasoning from childhood to adulthood. In W. Schneider \& M. Bullock (Eds.), Human development from early childhood to early adulthood: Findingsfrom a 20-year longitudinal study. Mahwah NJ: Erlbaum. [Електронний ресурс]. Доступно: https://psycnet.apa.org/record/2008-10321008

[4] D. Dean and D. Kuhn, "Direct instruction vs. discovery: The long view". Science Education, 2007, \#91, p.p 384-397. [Електронний pecypc]. Доступн: https://www.researchgate.net/publication/227601520_Direct_instruction_vs_Discovery_The_long_view

[5] Онлайн курси для освітян. Освітня платформа EdEra. [Електронний ресурс]. Доступно: https://www.ed-era.com/courses/

[6] Нова українська школа, сайт Міністерства освіти і науки України. [Електронний ресурс]. Доступно: https://mon.gov.ua/ua/tag/nova-ukrainska-shkola

[7] Кабінет Міністрів. (2019, Серп. 21). Постанова №800 Порядок підвищення кваліфікаиії педагогічних $i$ науково-педагогічних працівників. [Електронний ресурс]. Доступно: https://zakon.rada.gov.ua/laws/main/800-2019-\%D0\%BF

[8] PISA - дослідження заради якості освіти, портал. [Електронний ресурс]. Доступно: http://pisa.testportal.gov.ua/scho-vyvchaye-pisa/

[9] Ю.С. Мельник, В.В. Сіпій В.В. Формування предметної компетентності старшокласників у процесі навчання фізики. Київ, Україна: ТОВ «КОНВІ ПРІНТ», с. 136, 2018.

[10] Ю.О. Жук, О.М. Соколюк, Н.П. Дементієвська, І.В. Соколова, Інтернет-орієнтовані педагогічні технології у шкільному навчальному експерименті, Київ, Україна: Атіка, 2014

[11] Ю.О. Жук, О.М. Соколюк, Н.П. Дементієвська, О.В. Слободяник, Використання Інтернет технологій для дослідження природних явищ у шкільному курсі фізики. Київ, Україна: Атіка. 2014.

[12] L. David, Discovery Learning (Bruner), Learning Theories, 2017. [Електронний ресурс]. Доступно: https://www.learning-theories.com/discovery-learning-bruner.html.

[13] C. O'Connell, Inquiry-Based Science Education, Primer to the international AEMASE conference report, Rome, 19-20 May 2014, All European Academies (ALLEA). Berlin, Germany. [Електронний ресурс]. Доступно: https://allea.org/wp-content/uploads/2015/09/AEMASE-conference-report_Primer_digital.pdf

[14] National Science Education Standards. The Sourcebook for Teaching Science, [Електронний ресурс]. Доступно: https://www.csun.edu/science/ref/curriculum/reforms/nses/, https://www.csun.edu/science/ref/curriculum/reforms/nses/nses-complete.pdf

[15] M. Rocard, P. Csermely, D. Jorde, D. Lenzen, H. Walberg-Henrikson, and V. Hemmo, Science education now: A renewed pedagogy for the future of Europe. Brussels: European Commission: Directorate-General for Research. 2007. [Електронний pecypc]. Доступно: https://ec.europa.eu/research/sciencesociety/document_library/pdf_06/report-rocard-on-science-education_en.pdf

[16] C.W. Keys, L.A. Bryan, "Co-Constructing Inquiry-Based Science with Teachers: Essential Research for Lasting Reform", Journal of research in science teaching, 2001. vol. 38, no. 6, pp. 631-645

[17] N.M. Shamsudin, N. Abdullah, N. Yaamat, Strategies of Teaching Science Using an Inquiry Based Science Education (IBSE) by Novice Chemistry Teachers, 6th International Conference on University Learning and Teaching/ Procedia - Social and Behavioral Sciences, vol. 90, 2013. [Електронний pecypc]. Доступно: http://www.sciencedirect.com/science/article/pii/S187704281302017X

[18] A. Qablan, J. Al-Ruz, D. Theodora, and I. Al-Momani, "I know it's so good, but I prefer not to use it" An interpretive investigation of teachers' perspectives about learning biology through Inquiry". International Journal of Teaching and Learning in Higher Education, vol. 20 (3), pp. 394-404. 2009. [Електронний 
pecypc].

Доступно:

http://search.ebscohost.com/login.aspx?direct=true\&db=eric\&AN=EJ869324\&site=ehost-live

[19] J.R. Wang, S.W. Lin, "Examining Reflective Thinking: A Study of Changes in Methods Students' Conceptions and Understandings of Inquiry Teaching", International Journal of Science and Mathematics Education, vol. 6, no.3, pp. 459-479, 2008. [Електронний ресурс]. Доступно: https://eric.ed.gov/?id=EJ803495

[20] О.М. Соколюк, “Навчальні комп’ютерні моделі у пізнавальній діяльності учнів при вивченні предметів природничого циклу". Засоби і технології сучасного навчального середовища. Матеріали XV(XXV) міжнародної науково-практичної конференції (17-18 травня 2019 року). Ексклюзив-Систем, Кропивницький, Україна, с. 34-36.

[21] О.В. Слободяник, “Комп'ютерні моделі у дослідницькій діяльності учнів з фізики”, Фізикоматематична освіта, Суми, Україна, № 4(18), С.149-153, 2018.

[22] Н.П. Дементієвська, “Сайт інтерактивних симуляцій Phet як надійне і безпечне середовище для формування компетентностей учнів у природничо-математичних науках". Звітна наукова конференція Інституту інформаційних технологій $і$ засобів навчання ІІТЗН НАПН Украйни, Київ, Україна, с. 139-141, 2018.

[23] О.I. Ляшенко, С.I Терещук, “Застосування мобільної технології Plickers у процесі навчання фізики”, Інформаційні технології і засоби навчання, №70 (2). Київ, Україна. с. 59-70, 2019.

[24] I.D. Beatty, W.J. Gerace, W. J. Leonard, and R.J. Dufresne, "Designing effective questions for classroom response system teaching". American Journal of Physics. American Association of Physics Teachers. vol. 74, № 1(34). 2005. DOI: 10.1119/1.2121753 [Електронний ресурс]. Доступно: https://www.researchgate.net/publication/2173657_Designing_Effective_Questions_for_Classroom_Resp onse_System_Teaching

[25] J.M Hohloch, N.P. Grove, S.L. Bretz, "Pre-service Teacher as Researcher: The Value of Inquiry in Learning Science", Journal of Chemical Education, vol. 84(9), pp. 1530-1534, 2007. [Електронний pecypc]. Доступно: https://www.researchgate.net/publication/231267607_PreService_Teacher_as_Researcher_The_Value_of_Inquiry_in_Learning_Science

Матеріал надійшов до редакиї 04.05.2020 p.

\title{
ПОДГОТОВКА УЧИТЕЛЕЙ К ИСПОЛЬЗОВАНИЮ ИНТЕРАКТИВНЫХ КОМПЬЮТЕРНЫХ МОДЕЛЕЙ ДЛЯ ОБУЧЕНИЯ УЧЕНИКОВ ЧЕРЕЗ ИССЛЕДОВАНИЯ
}

\author{
Дементиевская Нина Петровна \\ научный сотрудник \\ Институт информационных технологий и средств обучения НАПН Украины, г. Киев, Украина. \\ ORCID ID 0000-0003-2985-3771 \\ nina.dementievska@gmail.com
}

\begin{abstract}
Аннотация. Система повышения квалификации учителей учебных заведений среднего образования начинает реформироваться. Учителя получают свободу повышать свой профессиональный уровень в негосударственных организациях, признаются приемлемыми различные формы такого обучения. Требования нового стандарта естествознания определяют умения, связанные с исследованиями. В статье описаны основные положения обучения, которое получило название Inquiry Based Science Education (обучение естественным наукам, основанное на исследованиях); обоснованно, почему обучение с исследованиями должно стать важным для образования учителей, преподающих предметы естествознания. Вызовы, стоящие перед учителями в соответствии с основными положениями НУШ и участия Украины в международном исследовании PISA, могут быть реализованы благодаря развитию новых форм повышения профессионального уровня учителей. Предлагается проведение тренинга по формированию у учащихся и учителей компетенций, связанных с обучением через исследования с использованием компьютерных моделей. Описана разработанная и апробированная программа обучения учителей использованию интерактивных моделей для обучения через исследования. В статье описаны некоторые элементы методики проведения тренинговых занятий $\mathrm{c}$ учителями, которые преподают предметы естественных наук, в частности при проведении фронтальных видов деятельности в
\end{abstract}


классе, при выполнении учащимися домашних заданий и для сопровождения практических и лабораторных работ. Эти виды деятельности выбраны с учетом результатов опроса учителей по обеспечению средствами ИКТ в классах, где они преподают. Упражнения тренинга опираются на особенности проведения занятий с учениками. Приведены онлайновые ресурсы и примеры упражнений, предлагаемых на тренинге для учителей физики и биологии, предложена последовательность проведения занятий с учениками. Обоснованы преимущества использования сервиса Plickers для получения и обработки мгновенных ответов учащихся как элемента формирующего оценивания при проведении фронтальных форм занятий с учащимися с использованием моделей при изучении физики, химии, биологии.

Ключевые слова: последипломное педагогическое образование; интерактивные компьютерные модели; обучение через исследование; естествознание; тренинг.

\title{
TEACHERS TRAINING ON THE USE OF INTERACTIVE COMPUTER SIMULATIONS FOR INQUIRY-BASED LEARNING
}

\author{
Nina P. Dementievska \\ researcher \\ Institute of Information Technologies and Learning Tools NAES of Ukraine, Kyiv, Ukraine \\ ORCID ID 0000-0003-2985-3771 \\ nina.dementievska@gmail.com
}

\begin{abstract}
The training system for teachers of secondary education is beginning to be reformed. Teachers have the freedom to increase their professional level through various forms, trainings are recognized as acceptable. The requirements of the new education standard in the science education define research-related skills. The article describes the basic principles of Inquiry Based Learning in comparison with the traditional learning, and substantiates why such learning should be important for the education of science teachers in secondary education. Challenges faced by teachers in accordance with the main ideas of the New Ukrainian School and Ukraine's participation in the international PISA research can be met by developing new forms of professional development for science teachers. In particular, training for students and teachers to develop competencies related to discovery learning through interactive computer simulations, is offered. The program of training for physics and biology teachers on the use of interactive simulations for teaching is described, for which the researches of other countries on such teacher training have been used. The article describes some elements of the methodology of conducting training sessions with teachers of science subjects, in particular when conducting interactive lecture activities in the classroom, for homework and to accompany practical and laboratory activities. These types of class activities are selected based on the results of a survey of teachers. The online resources and examples of exercises offered for the training of teachers of physics and biology are given, the sequence of conducting classes with the students is offered. The benefits of using the Plickers service to obtain and process students' instant responses as an element of formative assessment when conducting lecture classes with students, are substantiated.
\end{abstract}

Keywords: Inquiry-based learning; interactive simulations; science education; teacher training.

\section{REFERENCES (TRANSLATED AND TRANSLITERATED)}

[1] Cabinet of Ministers. (2018, Feb.21). Resolution №87 State Primary Education Standard. [Online]. Available:

https://www.kmu.gov.ua/npas/pro-zatverdzhennya-derzhavnogo-standartu-pochatkovoyi-osviti (in Ukrainian)

[2] D. Kuhn, What is Scientific Thinking and How Does it Develop? In U. Goswami (Ed.), Handbook of Childhood Cognitive Development (Blackwell), 2nd ed. 2010. [Online]. Available: https://www.tc.columbia.edu/faculty/dk100/facultyprofile/files/10_whatisscientificthinkingandhowdoesitdevelop.pdf 
[3] M. Bullock, B. Sodian, and S. Koerber, Doing experiments and understanding science: Development of scientific reasoning from childhood to adulthood. In W. Schneider \& M. Bullock (Eds.), Human development from early childhood to early adulthood: Findingsfrom a 20-year longitudinal study. Mahwah NJ: Erlbaum. [Online]. Available: https://psycnet.apa.org/record/2008-10321-008

[4] D. Dean and D. Kuhn, "Direct instruction vs. discovery: The long view". Science Education, 2007, \#91, p.p 384-397.

[Online].

Available: https://www.researchgate.net/publication/227601520_Direct_instruction_vs_Discovery_The_long_view

[5] Online courses for educators. EdEra educational platform. [Online]. Available: https://www.edera.com/courses/ (inUkrainian)

[6] New Ukrainian School, site of the Ministry of Education and Science of Ukraine. (in Ukrainian) [Online]. Available: https://mon.gov.ua/ua/tag/nova-ukrainska-shkola

[7] Cabinet of Ministers of Ukraine (2019, Aug. 21). Resolution No. 800 The order of professional development of pedagogical and scientific-pedagogical workers. [Online]. Available: https://zakon.rada.gov.ua/laws/main/800-2019-\%D0\%BF (in Ukrainian)

[8] PISA - exploration for quality of education, portal. [Online]. Available: http://pisa.testportal.gov.ua/schovyvchaye-pisa/ (in Ukrainian)

[9] Y.S. Melnik, and V.V. Sipiy, Formation of subject competence of high school students in the process of teaching physics. Kyiv, Ukraine: CONVI PRINT LLC. p. 136, 2018. (in Ukrainian)

[10] Y.O. Zhuk, A.M. Sokolyuk, N.P. Dementievska, and I.V. Sokolova, Internet - oriented educational technologies in school teaching experiment. Kyiv, Ukraine: Atika. (in Ukrainian)

[11] Yu.O. Zhuk, A.M. Sokolyuk, N.P. Dementievska, and O.V. Slobodianik, Internet technologies application for study of natural phenomena under the school physics course. Kyiv, Ukraine: Atika. 2014. (in Ukrainian)

[12] L. David, Discovery Learning (Bruner), Learning Theories, 2017. [Online]. Available: https://www.learning-theories.com/discovery-learning-bruner.html.

[13] C. O'Connell, Inquiry-Based Science Education, Primer to the international AEMASE conference report, Rome, 19-20 May 2014, All European Academies (ALLEA), Berlin, Germany. [Online]. Available: https://allea.org/wp-content/uploads/2015/09/AEMASE-conference-report_Primer_digital.pdf

[14] National Science Education Standards. The Sourcebook for Teaching Science, [Online]. Available: https://www.csun.edu/science/ref/curriculum/reforms/nses/, https://www.csun.edu/science/ref/curriculum/reforms/nses/nses-complete.pdf

[15] M. Rocard, P. Csermely, D. Jorde, D. Lenzen, H. Walberg-Henrikson, and V. Hemmo, Science education now: A renewed pedagogy for the future of Europe. Brussels: European Commission: Directorate-General for Research. 2007. [Online]. Available: https://ec.europa.eu/research/sciencesociety/document_library/pdf_06/report-rocard-on-science-education_en.pdf

[16] C.W. Keys, and L.A. Bryan, "Co-Constructing Inquiry-Based Science with Teachers: Essential Research for Lasting Reform," Journal of research in science teaching, vol. 38, no. 6, pp. 631-645, 2001.

[17] N.M. Shamsudin, N. Abdullah, and N. Yaamat, "Strategies of Teaching Science Using an Inquiry Based Science Education (IBSE) by Novice Chemistry Teachers," in 6th International Conference on University Learning and Teaching/ Procedia - Social and Behavioral Sciences, vol. 90, 2013. [Online]. Available: http://www.sciencedirect.com/science/article/pii/S187704281302017X

[18] A. Qablan, J. Al-Ruz, D. Theodora, and I. Al-Momani, "I know it's so good, but I prefer not to use it" An interpretive investigation of teachers' perspectives about learning biology through Inquiry," International Journal of Teaching and Learning in Higher Education, vol. 20 (3), pp. 394-404. 2009. [Online]. Available: http://search.ebscohost.com/login.aspx?direct=true\&db=eric\&AN=EJ869324\&site=ehost-live

[19] J.R. Wang, and S.W. Lin, "Examining Reflective Thinking: A Study of Changes in Methods Students' Conceptions and Understandings of Inquiry Teaching," International Journal of Science and Mathematics Education, vol. 6, no.3, pp. 459-479, 2008. [Online]. Available: https://eric.ed.gov/?id=EJ803495

[20] O.M. Sokolyuk, "Educational computer models in the cognitive activity of students in the study of subjects of the natural cycle," in Tools and technologies of modern educational environment. Proceedings of the XV (XXV) International Scientific and Practical Conference (May 17-18, 2019). Exclusive-System, Kropyvnytskyi, Ukraine, pp. 34-36. (in Ukrainian)

[21] O.V. Slobodianik, "Computer models in the research activity of students in physics," Physics and Mathematics Education, Sumy, Ukraine vol. 4 (18), pp. 149-153, 2018. (in Ukrainian)

[22] N.P. Dementievska, "PhET online simulation site as a reliable and safe environment for building students' competences in the natural sciences and mathematics," in Reporting Scientific Conference of the Institute of Information Technologies and Learning Tools of the NAES of Ukraine: materials of the scientific conference (March 27, 2018). Kyiv, Ukraine, pp. 139-141. 2018. (in Ukrainian) 
[23] O.I. Liashenko, S.I. Tereshchuk, "Using the mobile technology PLICKERS in the process of learning physics," Information Technologies and Learning Tools, vol. 2 (70). pp. 59-70. 2019. (in Ukrainian)

[24] I.D. Beatty, W.J. Gerace, W. J. Leonard, and R.J. Dufresne, "Designing effective questions for classroom response system teaching," American Journal of Physics. American Association of Physics Teachers, vol. 74, № $1(34), \quad 2005 . \quad$ DOI: 10.1119/1.2121753 [Online]. Available: https://www.researchgate.net/publication/2173657_Designing_Effective_Questions_for_Classroom_Resp onse_System_Teaching

[25] J.M Hohloch, N.P. Grove, and S.L. Bretz, "Pre-service Teacher as Researcher: The Value of Inquiry in Learning Science," Journal of Chemical Education, vol. 84(9), pp. 1530-1534, 2007. [Online]. Available: https://www.researchgate.net/publication/231267607_Pre-Service_Teacher_as_Researcher_ The_Value_of_Inquiry_in_Learning_Science

\section{(cc) BY-NC-SA}

This work is licensed under Creative Commons Attribution-NonCommercial-ShareAlike 4.0 International License. 